AgNIESZKa RogusKa

ORCID 0000-0001-9181-1500

Uniwersytet Przyrodniczo-Humanistyczny

$w$ Siedlcach

\title{
MŁODZIEŻ W OBSZARZE MEDIÓW LOKALNYCH W POLSCE I NA ŁOTWIE ${ }^{1}$
}

\begin{abstract}
Aвstract. Roguska Agnieszka, Młodzież w obszarze mediów lokalnych w Polsce i na Łotwie [Young People in the Local Media in Poland and Latvia]. Studia Edukacyjne nr 57, 2020, Poznań 2020, pp. 201-208. Adam Mickiewicz University Press. ISSN 1233-6688. DOI: 10.14746/se.2020.57.14

The article is aimed to present scientific results based on young people's activity in local media. It becomes even more interesting as the young generation is growing up in the era of global expansion, including media of a wide range scale of influence. This makes it even more interesting to trace how young people in Poland and Latvia understand local media. The research was carried out during three visits to Latvia: twice during an internship at Daugavpils University in 2014 and then at Riga Teacher Training and Educational Management Academy in 2015 and during the Erasmus + Project at Riga Teacher Training and Educational Management Academy in 2015. In the same period, similar studies were conducted at the Department of Humanities at Siedlce University of Science and Humanities. The study comprised a group of 160 young Polish and 108 Latvian university students aged 20-26 and was based on a diagnostic survey method. A survey and a questionnaire survey were used as tools, supported by interviews based on previously prepared tasks. The article discusses issues such as the need for local media functioning, the respondents' most frequently used media and the young people's participation in creating the content and the image of local media.
\end{abstract}

Key words: social communicating, local media, the youth, local media in Poland, local media in Latvia

\section{Wstęp}

W Polsce 2 kwietnia 2015 roku weszła w życie Ustawa o rozwoju lokalnym z udziałem lokalnej społeczności, tworząca podstawy prawne dla rozwoju lokalnego z udziałem społecznym. Jest to nowy instrument rozwoju

${ }^{1}$ Wyniki badań zrealizowane w ramach tematu badawczego pt. Młodzież akademicka w kontekście aktualnych problemów społecznych w Polsce i Europie zostały sfinansowane z dotacji na naukę, przyznanej przez Ministerstwo Nauki i Szkolnictwa Wyższego. 
terytorialnego Unii Europejskiej, wynikający z rozporządzenia unijnego nr 1303/2013. Ustawa ma sprzyjać aktywizacji lokalnej społeczności i włączać ją w podejmowanie decyzji dotyczących rozwoju ich regionu odnośnie na przykład: rozwoju przedsiębiorczości, pielęgnowania i upowszechniania lokalnego dziedzictwa, walki z różnymi formami wykluczenia społecznego ${ }^{2}$. Człowiek funkcjonuje przynajmniej w dwóch przestrzeniach: globalnej i lokalnej. Lokalność w tym tekście rozumiana jest jako najbliższe otoczenie funkcjonowania człowieka, dana społeczność cechująca się bliskością terytorialną, często interpersonalnymi kontaktami oraz rządami władz lokalnych.

Główną przesłanką podjęcia tego właśnie zagadnienia była obserwacja fascynacji młodych ludzi nowoczesnymi technologiami cyfrowymi. W związku z czym, nieco na przekór, zrodziło się pytanie odnośnie aktywności młodych ludzi w obszarze mediów lokalnych.

\section{Media lokalne w opinii młodych Polaków i Łotyszy w świetle badań}

Podwaliny teoretyczne badań stanowi teoria konstruktywizmu społecznego. Konstruktywizm jest znany z prac między innymi takich uczonych, jak: Peter Berger, Thomas Luckmann³, Erving Goffman, Michel Foucault, Horst Siebert, Mary Douglas. W teorii konstruktywizmu rzeczywistość społeczną traktuje się jako formę świadomości. Świat jest zbiorem reprezentacji tworzonych przez różne społeczności na własny użytek. Można zatem mówić o procesie interpretacji rzeczywistości społecznej, który jest udziałem wszystkich członków danego społeczeństwa, w tym społeczności lokalnych, a w obrębie nich - młodej generacji. Rzeczywistość nie jest constans, a nieustannie tworzona i przetwarzana. Zdaniem A. Gromkowskiej ${ }^{4}$, w tym podejściu teoretycznym, świat istnieje w postaci społecznie skonstruowanych znaczeń. Świadomość ludzka powstaje w wyniku więzi społecznych. Postrzeganie świata, otaczającej rzeczywistości przebiega w procesie następujących reakcji komunikacyjnych, obserwacji, zdobywanych doświadczeń oraz poszerzania zasobów wiedzy o świecie, w tym o najbliższym otoczeniu.

Badania dowiodły, że młodzi respondenci są pewni co do tego, że istnieje ogromna potrzeba funkcjonowania mediów lokalnych. Polacy opowiedzie-

${ }^{2}$ Ustawa z 20 lutego 2015 roku o rozwoju lokalnym z udziałem lokalnej społeczności, DzU 2015, poz. 378.

${ }^{3}$ P.L. Berger T. Luckman, The Social Construction of Reality: A Treatise in the Sociology of Knowledge, New York 1966.

${ }^{4}$ A. Gromkowska, Kobiecość w kulturze globalnej. Rekonstrukcje i reprezentacje, Poznań 2002, s. 16. 
li się w 75\%, a Łotysze w 89\% za obecnością na rynku medialnym mediów lokalnych. Jest to pocieszające $\mathrm{w}$ dobie ogromnego dostępu do wszelkiego rodzaju elektronicznych mediów, w tym mediów z wysoce rozwiniętą technologią, jak Internet, smartfony, tablety, media społecznościowe, czego dowodzą badania ${ }^{5}$. Młodzi ludzie używają ich bardzo często, a nawet nadużywają. Powoduje to dysproporcje w codziennie wykonywanych czynnościach czy sprzyja uzależnieniu od mediów, określanemu epidemią XXI wieku (21st Century epidemic).

Młodzi ludzie widzą potrzebę obecności mediów lokalnych w nurcie życia miejscowej społeczności, co jest budujące i dobrze rokuje na przyszłość pod względem ciągłości funkcjonowania mediów lokalnych. Obserwuje się natomiast tendencję odchodzenia od odbioru mediów działających $\mathrm{w}$ formie tradycyjnej na korzyść tych umieszczonych w Sieci, czyli na przykład lokalnych portali internetowych, mediów lokalnych on-line.

Z badań przeprowadzonych w 2009 i 2011 roku na grupie ponad 500 osób przez Polskie Badania Internetu, w ramach badania Omnibus Online, wynika, że aż 93\% internautów w wieku 18-54 lat wiedzę na temat swojej miejscowości (regionu) czerpie z Internetu. Poszerza się sukcesywnie zakres informacji tam poszukiwanych na temat, na przykład planowanych imprez i wydarzeń, wzrasta odsetek osób dzielących się informacjami o swoim regionie $^{6}$.

Pytanie o znaczenie lokalnych mediów dla miejscowego środowiska społeczno-kulturowego w Polsce i na Łotwie implikowało subiektywną ocenę mediów przez badanych w tej materii. Młodzi ludzie z Polski - 53,7\% i Łotwy - 48,1\% zadeklarowali, że media lokalne mają duże znaczenie dla obszaru, w którym funkcjonują.

Media w skali mikro pełnią różne funkcje ${ }^{7}$ - od informacyjnej, poprzez interwencyjną, rozrywkową, wzorcotwórczą, aż po edukacyjną i tym podobne. Badania ujawniły istotne znaczenie mediów lokalnych dla ludności

${ }^{5}$ C. Lincoln, Social Media Addiction: The Ultimate Guide to Finally Overcoming This Time-Consuming Addiction (Facebook Addiction, Twitter, Instagram, Tumblr, YouTube, Social Networking, Marketing, Dependency,) Kindle Edition 2013; D.J. Kuss, M.D. Griffiths, Internet Addiction in Psychotherapy (Palgrave Studies in Cyberpsychology), Series Editor: J. Binder, Nottingham 2104; B. Evans, Beating Life's Four Biggest Addictions: How to Have More Time for the Important Things (addiction, social media, internet, web rehab, life habits, technology, low info diet Book), Success First Publishing, Sold by: Amazon Digital Services LLC, 2014.

${ }^{6}$ H. Zaczkiewicz, S. Pliszka, Wiadomości lokalne w Internecie. Zawartość i popularność serwisów, profil użytkowników. Polskie badania Internetu; http://www.reporterzy.info/1650,internet-zdominowal-informacje-lokalne-telewizja-w-odwrocie.html, [dostęp: 01.03.2018].

7 A. Roguska, Media globalne - media lokalne. Zagadnienia z obszaru pedagogiki medialnej i edukacji regionalnej, Kraków 2012, s. 137-146; taże, Telewizja lokalna w upowszechnianiu kultury regionalnej, Kraków 2008, s. 125-142; W. Chorązki, Polskie media lokalne i sublokalne 1989-1999, Zeszyty Prasoznawcze, 1999, 1-2, s. 62. 
tam mieszkającej, propagowania i upowszechniania kultury regionalnej oraz poszerzania świadomości społecznej. Jest to optymistycznie prezentująca się wiadomość, podkreślająca duże przekonanie młodych ludzi co do ważności i potrzeby funkcjonowania mediów lokalnych w świecie ekspansji mediów globalnych i świecie medialnym, w którym oni sami są zanurzeni, poddani tak zwanej immersji.

Celem badań było poznanie między innymi zaangażowania młodych ludzi w kreację treści mediów lokalnych, czyli wpływanie na ich kształt i wizerunek. Pod hasłem kreowanie treści rozumie się następujące jej składowe: dostarczanie materiału, udzielanie wywiadu, przygotowywanie strony internetowej, zamieszczanie treści na lokalnym portalu internetowym, branie udziału w przedsięwzięciu lokalnym o różnym charakterze, które było prezentowane $\mathrm{w}$ mediach lokalnych i tym podobne.

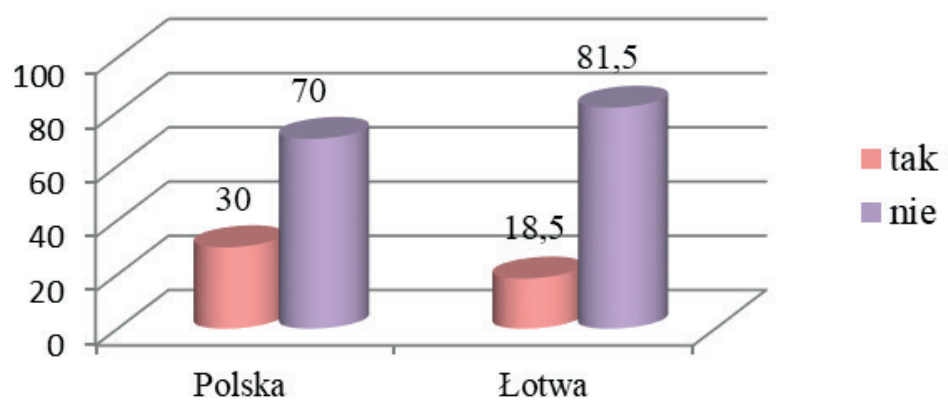

Ryc. 1. Młodzi ludzie w tworzeniu treści mediów lokalnych (w \%) w Polsce i na Łotwie (źródło: opracowanie własne)

Z danych przedstawionych na wykresie wynika, że kreowanie treści mediów lokalnych przez młodych ludzi zarówno w Polsce, jak i na Łotwie jest dosyć niskie: $30 \%$ w Polsce i zaledwie 18,5\% na Łotwie. Oznacza to, że badani bardziej nastawieni są na odbiór niż kreację treści. W pytaniach ankietowych otwartych odnośnie uzasadnienia braku aktywności w tej dziedzinie, respondenci nie wypowiedzieli się w tej kwestii. Natomiast, z wywiadów dowiadujemy się o: dostarczaniu materiału do realizacji programu, udzielaniu wywiadu, dawaniu ogłoszeń, wykonywaniu zadań zleconych przez realizatorów mediów lokalnych, obecności w mediach lokalnych z racji zainteresowań, na przykład artystycznych.

Ponadto, badania ujawniły niezbyt wysoką wiarę w poczucie sprawstwa użytkowników mediów lokalnych w kreowanie kształtu i wpływanie na ja- 
kość funkcjonowania najbliższego otoczenia. Lepiej pod tym względem od Polaków (34,4\%) wypadli młodzi Łotysze, ponieważ 40,7\% użytkowników miejscowych mediów opowiedziało się za tym, że użytkownicy mediów lokalnych mają wpływ na kształt i funkcjonowanie najbliższego otoczenia.

65,6\% badanych Polaków i 59,3\% Łotyszy jest zdania, że użytkownicy mediów lokalnych nie mają wpływu na funkcjonowanie najbliższego otoczenia. Niepokojące jest przekonanie młodych ludzi o ich nieskuteczności poczynań w kwestii wpływania swoją aktywnością za pośrednictwem mediów lokalnych na funkcjonowanie własnego otoczenia. Obie grupy badanych narodowości podobnie argumentowały swoje zdanie w tym względzie. Wskazywali, że z mediów lokalnych korzystają biernie, nie mają zaufania do przekazywanych treści lokalnych i jako jednostki nie wywierają większego wpływu na kształt otoczenia.

Na podstawie powyższych argumentacji możemy wnioskować, że respondenci nie wierzą $\mathrm{w}$ moc sprawczą czwartej władzy w postaci mediów lokalnych. Dostrzegają również jej stronnicze przekazy, na przykład reprezentowanie interesów swoich reklamodawców czy też obecnie panujących ugrupowań politycznych. Niektórzy respondenci uważają, że na realny kształt najbliższego otoczenia mają wpływ w głównej mierze włodarze miast, gmin, powiatów, województw. Zdarzały się również głosy, w których młodzi badani otwarcie pisali, że nie są zainteresowani udziałem $\mathrm{w}$ budowaniu wizerunku najbliższego otoczenia i wpływania na opinie odbiorców mediów lokalnych. Wynika to być może z młodego wieku badanych, innego rodzaju zainteresowań, realizacji zadań edukacyjnych, czy podejmowania pierwszej pracy i dbania o jej utrzymanie. Być może, jest to niska świadomość społeczna w kwestiach wyzwań demokratycznych i realizacji praw oraz obowiązków obywatelskich, również w obszarze swojego miejsca bytowania.

Wyjaśnienie tych kwestii wymaga podjęcia badań poszerzonych o tego typu aspekty obecności młodych ludzi w życiu społecznym. Polskie badania pod kątem uczestnictwa młodych ludzi w życiu społecznym, korzystania z praw obywatelskich, czy wypełniania obowiązku wyborczego nie pozostawiają złudzeń.

Frekwencja wyborcza w grupie 18-25 lat jest najniższa w kraju i należy do najniższych w Europie. Najmłodsza część elektoratu głosuje na ok. 20\% niższym poziomie niż starsi dorośli (54,1\% wyborców w wieku 18-25 wobec 73,1\% w wieku 56-65 w 2011 roku). To problem nie tylko w Polsce - w poprzednich wyborach do Parlamentu Europejskiego zagłosowało tylko 29\% Europejczyków poniżej 25. roku życia wobec $43 \%$ średniej dla całego elektoratu. Jedynie 14\% Polaków w wieku 18-24 lata deklaruje duże lub bardzo duże zainteresowanie polityką. To niepokojące dane, ponieważ to właśnie młodzież może wiele zmienić i to od jej aktywności wyborczej i społecznej będzie za- 
leżał przyszły kształt polskiego społeczeństwa - czy będzie ono bierne i nieaktywne, czy stanie się prawdziwym społeczeństwem obywatelskim ${ }^{8}$.

W badaniach na przestrzeni lat 1994-2013, zrealizowanych przez Fundację Centrum Badania Opinii Społecznej, a sfinansowanych przez Krajowe Biuro ds. Przeciwdziałania Narkomanii (KBPN), wśród adolescentów (uczniowie ostatnich klas szkół ponadgimnazjalnych: liceów, techników i zasadniczych szkół zawodowych w wieku 18-19 lat) odnośnie portretu młodych Polaków między innymi względem pojmowania i uczestnictwa w demokracji znalazło wydźwięk następujący:

Krytycyzm wobec funkcjonowania demokracji i negatywne oceny poszczególnych jej aspektów korespondują z opiniami na temat ogólnej sytuacji w kraju. Poglądy młodzieży w tej kwestii są najgorsze spośród dotychczas notowanych. Większość badanych jest zdania, że sytuacja w Polsce zmierza w złym kierunku (75\%), a tylko co dwudziesty (5\%) wyraża przeciwną opinię ${ }^{9}$.

Takie przekonanie może skutkować biernością wobec podejmowania inicjatyw obywatelskich, w tym wykorzystania narzędzi w postaci mediów lokalnych do aktywności społecznej.

Meryl Aldridge w swojej książce pisze: media lokalne są popularne, ważne, ale ignorowane. Podkreśla jednocześnie, że przede wszystkim funkcjonujemy w przestrzeni lokalnej ${ }^{10}$. Dla wielu ludzi ich najbliższe otoczenie jest bardzo ważne, chcą czuć się odpowiedzialni za podejmowane w ich sprawie decyzje, choć z rzeczywistą aktywnością na rzecz lokalnej społeczności już jest gorzej. Dobrze zorganizowane i aktywne wspólnoty lokalne wywierają wpływ na procesy decyzyjne na szczeblu lokalnym, oddziałują na władze samorządowe, terytorialne, uczestnicząc aktywnie w funkcjonowaniu własnej przestrzeni lokalnej.

\section{Zakończenie}

Młodzi są on-line i coraz częściej również media tradycyjne stają się on-line. Medialna przestrzeń globalna tworzy dogodne warunki dla rozwoju mediów lokalnych. W odbiorze mediów lokalnych jest to niezwykle ważne, szczególnie w przypadku młodej generacji, która rzeczywistość internetową

${ }^{8}$ A. Samel, Młodzi aktywni? Co zrobić, żeby młodzież brała udział w wyborach $i \dot{z} y c i u$ społecznym? http://www.ceo.org.pl/pl/sejmmlodziezy/news/mlodzi-aktywni-co-zrobic-zeby-mlodziez-brala-udzial-w-wyborach-i-zyciu-spolecznym, [dostęp: 02.03.2018].

${ }^{9}$ M. Herrmann, Młodzież o polityce, demokracji i gospodarce. Ocena funkcjonowania demokracji w Polsce, [w:] Młodzież 2013, Warszawa 2014, s. 52.

${ }^{10}$ M. Aldridge, Understanding The Local Media, Maidenhead 2007, s. 1, 2, 7. 
postrzega jako naturalne środowisko ich obecności i aktywności. Z przeprowadzonych badań wynika, że informacji lokalnych młodzi polscy i łotewscy respondenci szukają właśnie w medium globalnym, czyli Internecie, z udziałem portali społecznościowych, blogów, komunikatorów, lokalnych mass mediów w sieci i tym podobnych.

Podsumowując, badania dowodzą, że młodzi ludzie w Polsce i na Łotwie dostrzegają potrzebę funkcjonowania mediów lokalnych w ich krajach. Najchętniej korzystają z lokalnych portali internetowych. Respondenci podkreślali znaczenie mediów lokalnych dla ludności tam mieszkającej, propagowanie i upowszechnianie przez nie kultury regionalnej oraz poszerzanie świadomości społecznej. Wyniki badań napawają optymizmem, ale jednocześnie niepokoją, ponieważ brakuje aktywnego włączania się młodych ludzi w funkcjonowanie mediów lokalnych, kreowanie ich wizerunku i jakości przekazów. Młodzi ludzie bardziej nastawieni są na odbiór niż kreację treści. Badania ujawniły średnią wiarę w poczucie sprawstwa użytkowników mediów lokalnych $w$ kreowanie kształtu i wpływanie na jakość funkcjonowania najbliższego otoczenia. Nieco lepiej pod tym względem od Polaków w badaniach zaprezentowali się młodzi Łotysze.

Badania ujawniły jeszcze wartość nie zakładaną wcześniej w badaniach, a wynikłą po analizie zgromadzonego materiału. Dotyczy ona braku edukacji lokalnej. Potrzebna jest nam edukacja globalna, ale jednocześnie zachodzi konieczność także edukacji lokalnej. Te dwa procesy, pola aktywności nie wykluczają się wzajemnie, a przeciwnie - uzupełniają się. Edukacja lokalna i globalna podejmują podobne zagadnienia, z tym że ta pierwsza w przestrzeni mniejszej, bliskiej, jednostkowo oswojonej. Chodzi tu o rozwijanie zdolności myślenia w przestrzeni swojego rzeczywistego, realnego funkcjonowania. Poza tym, o wyposażenie młodzieży w zakres kompetencji nie tylko odnośnie wiedzy o najbliższym otoczeniu, zachodzących tam przemian, ich prawidłowości, ale także kompetencji społecznych, analitycznego i krytycznego poruszania się w przestrzeni publicznej, w tym medialnej. Istotne staje się w tych obszarach edukacji ukazanie związków pomiędzy zakorzenieniem ludzi we wspólnotach lokalnych a ich funkcjonowaniem na poziomie narodowym i globalnym.

\section{BIBLIOGRAFIA}

Aldridge M., Understanding The Local Media, Open University Press, Maidenhead 2007.

Berger P.L., Luckman T., The Social Construction of Reality: A Treatise in the Sociology of Knowledge, Harmondsworth, New York 1966.

Chorązki W., Polskie media lokalne i sublokalne 1989-1999, Zeszyty Prasoznawcze, 1999, 1-2. 
Evans B., Beating Life's Four Biggest Addictions: How to Have More Time for the Important Things (addiction, social media, internet, web rehab, life habits, technology, low info diet Book), Success First Publishing, Sold by: Amazon Digital Services LLC 2014.

Gromkowska A., Kobiecość w kulturze globalnej. Rekonstrukcje i reprezentacje, Wydawnictwo Wolumin, Poznań 2002.

Herrmann M., Młodzież o polityce, demokracji i gospodarce. Ocena funkcjonowania demokracji w Polsce, [w:] Młodzież 2013, Centrum Badania Opinii Społecznej, Krajowe Biuro ds. Przeciwdziałania Narkomanii, Warszawa 2014.

http:/ / www.reporterzy.info/1650,internet-zdominowal-informacje-lokalne-telewizja-w-odwrocie.html, [dostęp: 01.03.2018].

Kuss D.J., Griffiths M.D., Internet Addiction in Psychotherapy (Palgrave Studies in Cyberpsychology), Series Editor: J. Binder, Nottingham Trend University, UK 2104.

Lincoln C., Social Media Addiction: The Ultimate Guide to Finally Overcoming This Time-Consuming Addiction (Facebook Addiction, Twitter, Instagram, Tumblr, YouTube, Social Networking, Marketing, Dependency), Kindle Edition 2013.

Roguska A., Telewizja lokalna w upowszechnianiu kultury regionalnej, Oficyna Wydawnicza Impuls, Kraków 2008.

Roguska A., Media globalne - media lokalne. Zagadnienia z obszaru pedagogiki medialnej i edukacji regionalnej, Oficyna Wydawnicza Impuls, Kraków 2012.

Samel A., Młodzi aktywni? Co zrobić, żeby młodzież brała udział w wyborach i życiu społecznym? http://www.ceo.org.pl/pl/sejmmlodziezy/news/mlodzi-aktywni-co-zrobic-zeby-mlodziez-brala-udzial-w-wyborach-i-zyciu-spolecznym, [dostęp: 02.03.2018].

Ustawa z 20 lutego 2015 roku o rozwoju lokalnym z udziałem lokalnej społeczności, DzU 2015 poz. 378.

Zaczkiewicz H., Pliszka S., Wiadomości lokalne w Internecie. Zawartość i popularność serwisów, profil użytkowników, Polskie Badania Internetu 2017. 